\title{
PSICHODIAGNOSTINIŲ TYRIMŲ TAIKYMAS EKSPERTINĖJE PRAKTIKOJE
}

\author{
Gintaras Butkus \\ Valstybine teismo psichiatrijos tarnyba prie Sveikatos apsaugos ministerijos
}

Raktažodžiai: psichologinis tyrimas, psichologinė ekspertizè, normatyvinè ir interpretacinè paradigma.

\begin{abstract}
Santrauka
Straipsnyje analizuojami teismo psichologo eksperto veiklos metodologiniai klausimai: kas yra psichologinis tyrimas teismo psichologo eksperto praktikoje, kuo skiriasi toks tyrimas nuo tradicinio tyrimo klinikinejje praktikoje, kuo skiriasi ir panašūs teismo psichologo eksperto atliekamos ekspertizès ir psichologiniai tyrimai, kaip derinami kokybinio ir kiekybinio tyrimo principai.
\end{abstract}

\section{Ivadas}

Teismo psichologo eksperto Lietuvoje veikla glaudžiai susijusi su klasikine psichodiagnostikos paradigma. Klinikinè psichodiagnostika - vienas seniausių medicininiu terminų, apimantis visus klinikinius metodus, nustatant psichikos sutrikimus. Psichologinis tyrimas - sudetine klinikinès psichodiagnostikos dalis. Teismo psichiatrijos ekspertizèse kaip tik toks naudojamas terminas, kuriuo apibendrinimas teismo psichologo indèlis $i$ teismo psichiatrijos ekspertizės akto surašymą. Tuo tarpu gydomosios medicinos praktikoje ir teorijoje dažniau vartojamos sąvokos „psichologinis testavimas“, ,psichologinè diagnostika“ ir paskutiniu laiku populiariausias terminas - „psichologinis vertinimas“ (11). Tokia sąvoka kaip „psichologinis testavimas" empiriškai aiškiausia, tačiau kartu ir pati siauriausia - asmenybès ir pažintinių procesų vertinimas atliekamas naudojant testus. Šiame kontekste klinikinio psichologinio vertinimo kokybè išskirtinai siejama su ,gerų testų“ parinkimu ir atlikimu (6). „Gerais testais“ pripažistami tik tokie, kurie turi: a) standartizuota procedūrą, b) leistu daryti išvadas apie visą sritị, kurią atitinka matuojamas elgesys, c) rezultatų suvestinę lygintų su reprezentacinès imties normos ribomis, d) patikimumo ir validumo garantijas. „Gero testo“ tipinis pavyzdys - Wechslerio suaugusiuju intelekto skalè, trečias leidimas (sutrumpintai - WAIS-III).
Tokių testų praktinè nauda nekvestionuojama, tačiau ta pati praktika rodo, kad psichologinio tyrimo tikslai gali būti žymiai sudètingesni nei kokios nors siauros srities matavimas, todèl iškyla būtinybė vertinti sudètingas asmenybès, aplinkos sąlygų ir elgesio sąsajas, derinti skirtingus duomenų rinkimo metodus (interviu, testai, stebėjimas), tikrinti tyrimo eigoje nustatomas prielaidas, integruoti nustatytą duomenų ịvairovę, interpretuoti bei formuluoti apibendrinamąsias individualizuotas išvadas, siejant su konkrečiomis tiriamo asmens problemomis ir jo realybe, išplečiant sunkumų supratimą (8). Tokiu būdu šiuolaikinèje praktikoje sudètingam psichologiniam tyrimui produktyviai atlikti neišvengiama pusiausvyra tarp normatyvinès (kiekybinès) ir interpretacinès (kokybinès) paradigmos. Tuo tarpu Lietuvos psichologu sajungos Psichikos sveikatos komiteto iniciatyva 2013 metais parengtu klinikinio psichologinio vertinimo rekomendacijų apraše apsiribota tik adaptuotų/adaptuojamų Lietuvai instrumentu pateikimu. Žinoma, praktikoje naudojami psichodiagnostikos metodai turi atitikti būtinus standartizacijos, validumo, patikimumo psichometrinius reikalavimus, tačiau išskirtiniu demesiu normatyvinei paradigmai pernelyg sureikšminama metodo svarba, investuojama ị techninių metodo savybių tobulinimą, ignoruojant tyrejjo ir tiriamojo santykių kontekstą, ịvairius situacinius ir motyvacinius veiksnius. Kita vertus, kokybinių tyrimų problemos susijusios su mokslinių kriterijų, ypač validumo, išskyrimo sunkumais. Analizuojant ịvairias validumo formas ir jų igyvendinimą, aprašomos tokios validumo kategorijos kaip tiketinumas, autentiškumas, kritiškumas ir integralumas (7). Tiketinumas suprantamas kaip tyrejo pastangos pagristi, kad duomenų interpretacija yra patikima, pasitelkiant metodų, duomenų, skirtingų tyrèjų trianguliaciją. Autentiškumo kriterijumi siekiama atsakyti, ar atlikto tyrimo duomenys pakankamai atitinka tikrovę ir jais galima pasiremti, darant išvadas. Kritiškumas gali būti pasiekimas lyginant alternatyvas, integralumas - sistemiškai tikrinant, kad prielaidos kyla iš duomenų. Grindžiamosios paradigmos autoriai pabrèžia, kad kokybinio tyrimo 
efektyvumas labiau nei kiekybinio priklauso nuo viso tyrimo organizavimo, tyrejjo kompetencijos ir ịgūdžių bei jo asmenybès $(3,12)$. Tokiu būdu, atliekant kokybinį tyrimą, tyrejas privalo išmanyti bendraji tiriamo reiškinio lauką, operacionalizuoti tyrimo tikslą i atskiras užduotis, pasižymèti pastabumu, gerais indukcinio mąstymo igūdžiais, nes analizuodamas atvejus turètu gebėti generuoti naujas struktūras ar kurti naujus konceptus, t. y. kokybinëje paradigmoje tyrimo laukas glaudžiai siejamas su tyreju kaip holistine visuma.Straipsnio probleminis klausimas - kaip normatyvinè (kiekybinè) ir interpretacinè (kokybinè) tyrimo strategijos integruojamos teismo psichologo eksperto veikloje?

Straipsnio tikslas: išanalizuoti teismo psichologo eksperto darbo veiklos metodologinius ypatumus bei ịvertinti psichologinès ekspertizès praktinị poreikị perspektyvoje.

\section{Tyrimo medžiaga ir metodas}

Tyrimo tikslu išanalizuota teisine ekspertinio darbo dokumentacija, mokslinè psichologinio vertinimo literatūra bei teismo psichologo praktinès veiklos produkcija.

Teismo psichologo eksperto situacija: ekspertizė vs psichologinis tyrimas; normatyvinè paradigma vs interpretacinè paradigma. Pagal VTPT prie SAM ekspertizių nuostatas teismo psichologai ekspertai savo darbe atlieka teismo psichologijos ekspertizes ir psichologinius tyrimus, kurie septintame kompleksinès teismo ekspertizès darymo ypatumu skyrelyje pažymèti kaip psichologo konsultacinè pagalba. Skiriamos dvi teismo psichologijos ekspertizès atmainos, kurių tikslai ir uždaviniai turi skirtumo požymių: a) psichologijos ekspertizè, kaip sudètinė kompleksinès psichiatrijos-psichologijos dalis, b) psichologijos ekspertizè, kaip vienasmenès ekspertizès atmaina. Praktikoje vienasmenès teismo psichologijos ekspertizès suaugusiems asmenims pasitaiko itin retai. Iš vienos pusès, vienasmenių teismo psichologijos ekspertizes riboja daugelio VTPT skirtu ekspertizių medicininio kriterijaus išaiškinimo būtinybè, t. y. teismo psichologijos ekspertizè kaip vienasmenès ekspertizès atmaina atliekama tik tais atvejais, kai teismo proceso dalyvių, kurių atžvilgiu paskiriama ekspertizè, psichikos sveikata nekelia abejonių, todėl pakanka tik specialių sisteminių teismo psichologijos žinių. Klasikiniu precedentu laikytini asmenų emocinès būsenos juridiškai reikšmingoje situacijoje ypatumų, teismui svarstant tokią baudžiamają atsakomybę šalinančią aplinkybę kaip būtinoji gintis dèl didelio sumišimo ir ar išgąsčio, vertinimo atvejai. Tuo tarpu kita psichologinių ekspertizių lauką siaurinanti priežastis glūdi ne tarpdisciplinineje sankirtoje, o pačioje teismo psichologijos praktikoje. $2003 \mathrm{~m}$. Europos Tarybos Ministrų komitetas rekomendacijoje Nr. R (2003) 20, nuosekliai skirdamas dėmesi jauniems pilnamečiams, pabrěžè, jog valstybėms narèms svarbu numatyti galimybes, kad asmenims iki $21 \mathrm{~m}$., teisèjui nusprendus, jog pagal brandą ir atsakingumą jie neprilygsta suaugusiems, būtų taikomos nepilnamečiams numatytos procesinès taisyklès bei intervencija (5). LAT pabrèžia, kad tiriant socialinès brandos lygi pagrindiniu nagrinèjimo objektu turètu būti ne tiek pati nusikalstama veika, kiek ,jaunatviškas, paaugliškas“" mąstymo būdas, veikimo priežastys, elgesys prieš nusikalstamos veikos padarymą bei po jo ir kt. Tokiam aplinkybiu turiniui nustatyti svarbu, jog visapusiška informacija apie aplinkybes, kurias vertindamas teisèjas turètų nuspręsti, ar asmuo pagal socialinę brandą prilygsta nepilnamečiui, būtų surenkama ikiteisminio tyrimo metu ir teisejjas, spręsdamas ši klausimą, disponuotų pakankamomis žiniomis apie jaunuolio gyvenimo būdą, nusikalstamos veikos padarymo aplinkybes, jo paties požiūrị ị savo veiką. $2007 \mathrm{~m}$. atliktas LR teisèjų nuomonès tyrimas atskleidè palankias jų nuostatas BK 81 str. 2 d. atžvilgiu, tačiau drauge buvo nustatyta, kad teisėjai susiduria su problemomis ir neaiškumais, vertinant socialinę brandą, nes ịstatyme nekonkretizuojama, kaip ji suprantama, nèra ịteisintos metodikos ją nustatyti, o specialistai (tikètina, - psichologai), kurie galètu padèti ivvertinti jauno pilnamečio socialinę brandą, dažniausiai atsisako (13). Tokia negatyvi praktika sąlygota socialinès arba lygiagrečiai dažnai vartojamo kito termino - psichosocialinès, - brandos kriterijaus neaiškumo bei atitinkamų metodikų nebuvimo, t. y. pripažistama aklavietè normatyvinès paradigmos kontekste. Kita vertus, Vokietijos, šalies, kurioje baudžiamosios teisés normos, skirtos jauniems pilnamečiams, yra apsvarstomos kaskart, sprendžiant jaunuolio baudžiamają bylą ir taikomos labai dažnai, Aukščiausiasis Federalinis Teismas išaiškino, jog jaunas pilnametis pagal brandą prilygintinas nepilnamečiui, jei „elementai rodo, jog ženklus asmenybès vystymasis dar laukia ateityje“. Teismas remiasi ne įsivaizduojamu nepilnamečiu (jo prototipu), bet kaskart vertina kiekvieno asmens brandą ir vystymąsi. Teismo psichologijos ekspertizių praktikoje nerealizuojama dar vienas ịstatymo leidejo įtvirtinta nuostata - įvertinti asmenu individualius psichologinius asmenybejs ir elgesio prognozès ateityje ypatumus, kurie gali būti teismui naudingi, svarstant baudžiamosios atsakomybès ir bausmès skyrimo ribas.Tokiu būdu tiek asmenų emocinès būsenos juridiškai reikšmingoje situacijoje, tiek socialinès brandos, tiek asmenų individualių psichologinių asmenybès ir elgesio prognozès ateityje psichologinis vertinimas ir atitinkamos rekomendacinès išvados teismui teikimas reikalauja ne tiek normatyvinès, kiek interpretacinès paradigmos išmanymo ir praktinio pritaikymo atvejo analizès pavidalu. Tuo tarpu teismo psichologijos ekspertizè, kaip 
sudètinè kompleksinès psichiatrijos-psichologijos dalis, atliekama tais atvejais, kai teismo proceso dalyvių, kurių atžvilgiu paskiriama ekspertizè, psichikos sveikata turi sutrikimo požymių, todèl reikalingos ne tik specialios klinikinès psichologijos, bet ir, visų pirma, specialios teismo psichiatrijos žinios. Pavyzdžiui, siekiant nustatyti teismo baudžiamojo proceso dalyvių gebėjimą, atsižvelgiant i jų protinio išsivystymo lygį, emocinę būseną suvokimo metu, individualias psichologines asmenybès ypatybes bei situacijos ypatumus, teisingai suvokti reikšmingas bylai aplinkybes ir duoti apie tai parodymus, atliekamas sudetinis psichologinis intelekto, asmenybès, elgesio juridiškai reikšmingoje situacijoje vertinimas. Taigi, ekspertas privalo pateikti specialias žinias, remdamasis kiekybinio (testai) ir kokybinio tyrimo strategijomis. Tik tokia psichologo išplèstine išvada tampa svarbia ne tik psichiatro medicininiam kriterijui išaiškinti, bet ir teikia teismui naudingas žinių teisiniam kriterijui papildyti. Atliekant psichologinius tyrimus, kai teismo psichiatrijos ekspertizès metu teismo psichiatrams ekspertams atsakyti i pateiktus klausimus reikia tik psichologo konsultacinès pagalbos, didesni svorị turi normatyvinès paradigmos principų taikymas, kadangi paprastai išskiriamos aiškiai apibrěžtos diferencinès diagnostikos užduotys: ịvertinti tiriamųų asmenų kognityvinius procesus, bendruosius gebejjimus, asmenybès, emocinès savireguliacijos, nuotaikos ypatumus bei psichologinius-socialinius išteklius. Tokioms užduotims atlikti pasitelkiami tradiciniai duomenų rinkimo būdai - psichologiniai testai, klinikinès skalès, projekcinès metodikos ir technikos, - t. y. pilnai taikomi gydomojoje medicinineje praktikoje paplitę psichologinio testavimo principai. Kita vertus, psichologiniai tyrimai ekspertizès kontekste turi esminių skiriamujų požymių. Pirma, ị medicinos įstaigas besikreipiantys asmenys turi juos varginančių simptomų, todèl tiek psichiatras, tiek psichologas, tiek klientas turi tą patį tikslą - suprasti visų simptomų sunkumo laipsnį ir juos tinkamai koreguoti, mažinant subjektyviai patiriamą kančią. Tuo tarpu teismo ekspertizès yra teismo ar teisèjo paskirtas proceso veiksmas, todèl užsakovo ir tiriamojo interesai gali iš esmès skirtis: užsakovas tikisi objektyvių ekspertizès ir psichologinio tyrimo duomenų ir išvados, tuo tarpu tiriamasis kaip tik gali būti nesuinteresuotas nustatyti tiesą. Tokiu atveju atliekant psichologinị tyrimą, galimos simuliacijos, agravacijos ar metasimuliacijos apraiškos. Galima ir priešinga disimuliacijos nuostata. Tyrimo duomenys gali būti iškreipiami ir tiriamojo regresinio tipo psichologinemis gynybomis, reaguojant ị tyrimu indukuojamą ar dèl teisminio proceso patiriamą, o ekspertine situacija sustiprinamą stresą. Bet kokiu atveju psichologo ir tiriamojo bendradarbiavimas pasunkejjęs, todèl atitinkamai turi būti modeliuojami tarpusavio santykiai, sustiprintas tiriamojo elgesio, žodinių pranešimų, testais gautų rezultatų palyginimas, motyvacijos, o kartu ir asmenybès elgesio tyrimo situacijoje apibendrinimas, t. y. psichologinis tyrimas ekspertizių kontekste neišvengiamai turi interpretacinès paradigmos požymių. Antra, ekspertizei pateikiama visa reikalinga baudžiamosios bylos ir medicininès dokumentacijos medžiaga, kurioje gali būti ankščiau atliktų psichologinių tyrimų duomenys ir išvados, kiti šaltiniai, galintys turèti reikšmę apibendrinančiai psichologinio vertinimo išvadai. Itvairių šaltinių duomenys turètų būti lyginami, atsižvelgiant i jų patikimumą ir validumą. Pavyzdžiui, turetų būti vertintinas anksčiau atliktų tyrimų autentiškumo kriterijus pagal tai, kiek tyrejjai atsižvelge ị tyrimo situaciją, tiriamojo motyvaciją, kokias metodikas taikè, kaip lygino jų rezultatus su stebejjimo, interviu duomenimis. Tik atlikus sisteminę analizę, galima teikti apibendrinančią išvadą ne tik apie matuojamo požymio charakteristiką, bet ir jo dinamiką bei tikètinumą. Kitaip tariant pilnavertis psichologinis tyrimas teismo psichiatrijos ekspertizès kontekste reiškia ne tik psichodiagnostini vertinimą ,geru testu“, bet ir duomenų trianguliaciją.Tokiu būdu bet koks psichologinis tyrimas teismo ekspertizėse turi atvejo analizès požymių, tuo iš esmès skirdamasis nuo daugelio psichodiagnostinių tyrimų, psichologų atliekamų klinikineje praktikoje. Tokias prielaidas būtų galima pademonstruoti tipiniu atveju teismo psichiatrijos ekspertizèse, kuriose psichologų prašoma įvertinti tiriamų asmenų, kuriems praeityje buvo diagnozuoti ivairaus sunkumo nuotaikos sutrikimai, emocinius ir kognityvinius ypatumus. Klinikiniai psichologai paprastai tokiais atvejais pateikia kelis testus: standartizuotą MMPI metodiką, klinikines depresijos vertinimo skales, dažniausiai Becko skalę, bei projekcines - HTP, piktogramas. Kiekviena atskirai naudojama metodika turi nemažus apribojimus. MMPI ir ypač klinikinès skalès itin priklauso nuo tiriamojo pozityvios motyvacijos, nuoširdumo, MMPI apribota refleksijos, dèmesio koncentracijos išlaikymo ir normalaus intelekto reikalavimų. Daugeliu atvejų rezultatų patikimumas gali būti paveiktas išsiblaškymo, astenijos ar pseudodemencijos fenomeno, reikšmingai paveiktas tiriamojo neigiamo ar nenuoširdaus požiūrio ị atvirai užduodamus klausimus apie savijautą ir kasdienį funkcionavimą. Klinikiniai psichologai savo išvadose gali tik palyginti skirtingomis metodikomis gautus rezultatus (pavyzdžiui, Becko skalejje nustatytą bendrą balų sumą su piešinių metodikos grafiniais ypatumais ar šoko reakcijomis piktogramose), tačiau skirtingų tyrèjų gautų duomenų trianguliacija bei kognityvinių ypatumų vertinimas lieka nuošalyje. Teismo ekspertizès situacijoje pašaliniai trikdžiai - tiriamojo reakcija ị savo procesinị statusą, ateities lūkesčiai, stresas 
dèl atliekamos ekspertizès - iš esmès komplikuoja tokių metodikų kaip MMPI ar klinikinès skalès panaudojimą. Psichologinio tyrimo, atliekamo teismo psichiatrineje ekspertizèje dèl nuotaikos sutrikimo kvalifikavimo, pagrindiniu uždaviniu formuluojamas ne depresiškumo tendencijos nustatymas, o tiriamojo psichologinès nuostatos i juridiškai reikšmingą situaciją bei atliekamą tyrimą nustatymas, dvejopo elgesio tikimybės bei subtiliujų depresijos kognityvinių požymių vertinimas. Pastarojo uždavinio realizavimo pagrindas - neuropsichologinio vertinimo paradigma $(2,4)$. L. G. Kiloh (1961) pasiūlytas pseudodemencijos terminas, kuri E. D. Caine (1986) pritaikè sergantiesiems depresija vyresniame amžiuje, pavadindamas kliniškai stebimą kognityvinị deficitą pseudodemencijos sindromu, neuropsichologinių tyrimų kryptyje igavo aiškesnę verifikacinę ir mažiau stigmatizuotą reikšmę - specifinis intelekto funkcionavimas $(1,10)$. Aprašant neuropsichologinių tyrimų duomenis, iš visų specifinių atminties, psichomotorinio greičio ir kalbos sunkumų galima būtų išskirti tuos, kurių simuliacija ar agravacija būtų itin komplikuota, todèl sąlyginai vadintini subtiliaisiais kognityvinių sutrikimų požymiais, skiriant nuo klasikinių, bet tuo pačiu akivaizdžiai stebimų ir lengvai kopijuojamų, tokių kaip sulètejęs protinio darbingumo tempas, dèmesio paskirstymo sunkumai. R. P. Hart ir J. A. Kwentus (1987) atliko tyrimą su keliais WAIS-R subtestais, lygindamas grupinius skirtumus tarp pagyvenusiu asmenų su depresija ir kontrolinès sveiku asmenų grupès (9). Išvadose konstatuota, kad gautas kliniškai reikšmingas skirtumas atliekant skaičių simbolių - kodavimo užduotị, tačiau statistiškai reikšmingas skirtumas atliekant savaiminio išmokimo bei informacijos užduotị nenustatytas. Tokiu būdu atliekant depresinių atvejų psichologinį tyrimą ekspertizès kontekste, kai svarbu atsižvelgti ị situacinius ir motyvacinius veiksnius, tikrinant alternatyvias hipotezes, būtinas mokslinių tyrimų žinojimas ir jų modeliavimas teismo psichologo darbe. Mūsų pateiktoje psichologinio tyrimo schemoje išskirtume ne tik minètų subtestų standartinių balų palyginimą tarpusavyje, bet ir su referentinès grupès balais, atlikti darbinès atminties ir psichomotorinio greičio indeksų palyginimą, pasirinktinai atlikti asociacinių metodikų (piktogramų, K. G. Jungo, 60 žodžių) tyrimus, analizuojant kiekybinius ir kokybinius parametrus i skirtingą emocinį krūvị turinčias sąvokas.

\section{Išvados}

1. Teismo psichologo eksperto psichologinių tyrimu metodinis sudetingumas priklauso nuo to, ar atliekama vienasmenè teismo psichologijos ekspertizè, ar psichologinis tyrimas teismo psichiatrijos ribose. Sudetingumas susijęs su kiekybinio ir kokybinio tyrimo proporcija.
2. Psichologiniai tyrimai teismo psichiatrijos ekspertizès kontekste turi interpretacinès paradigmos, atvejo analizės, kokybinio tyrimo požymių, kurių variacija priklauso nuo užsakovo keliamų tikslų.

3. Teismo psichologų ekspertų perspektyvinis uždavinys - suteikti teismams specialiujų žinių apie asmenų individualias psichologines asmenybès, tarp jų brandos ir tikètinos elgesio korekcijos ateityje prielaidas, kurios gali būti teismui naudingos, svarstant baudžiamosios atsakomybès ir bausmès skyrimo ribas.

\section{Literatūra}

1. Caine ED. The neuropsychology of depression: The pseudodementia sindrome. In Grant I, Adams K. (Eds.), Neuropsychological assessment of neuropsychiatric disorders. New York: Oxford University Press 1986; 221-243.

2. Nussbaum PD, Robins DL. (Eds). Clinical Neuropsychology: a Pocket Handbook for Assessment. Washington: American Psychological Association, 2006.

3. Cropley A. Qualitative Research Methods. An Introduction for Students of Psychology and Education. Rīga: Zinātne, 2002.

4. Darby D, Walsh K. Walsh's Neuropsychology: A Clinical Approach. Edinburg: Elsevier/Churchill Livingstone, 2005.

5. Recommendation No. R (2003) 20 of the Committee of Ministers to member states concerning new ways of dealing with juvenile delinquency and the role of juvenile justice. Adopted by the Committee of Ministers on 24 September 2003, at the 853 meeting of the Ministers' Deputies.

6. Gintilienė G. Kaip atpažinti gerą testą. Klinikinis psichologinis vertinimas Lietuvoje: problemos ir galimybès. Konferencijos medžiaga, Vilnius, 2011;16-18.

7. Guba EG, Lincoln YS. Paradigmatic controversies, contradictions, and emerging influences. In N. K. Denzin \& Y. S. Lincoln (Eds.), The Sage Handbook of Qualitative Research (3rd ed.). Thousand Oaks, CA: Sage, 2005; 191-215.

8. Gudaitė G. Klinikinis psichologinis vertinimas: užduotys ir taikymo principai. Vilnius: VU leidykla, 2007.

9. Hart RP, Kwentus JA. Psychomotor slowing and s\&corticaltype dysfunction in depression. Journal of Neurology, Neurosurgery and Psychiatry 1987; 50:1263-1266.

http://dx.doi.org/10.1136/jnnp.50.10.1263

10. Kiloh LG. Pseudodementia. Acta Psychiatr Scand 1961; $37: 336-51$

http://dx.doi.org/10.1111/j.1600-0447.1961.tb07367.x

11. Dembinskas A. Psichiatrija (vadovèlis). Vilnius: UAB "Vaistų žinios", 2003.

12. Strauss A, Corbin J. Basics of Qualitative Research Techniques and Procedures for Developing Grounded Theory (2nd edition). London: Sage Publications, 1998.

13. Ūselè L. Jaunų pilnamečių (18-20 metų) socialinė branda nepilnamečių baudžiamosios atsakomybès ypatumų jiems 
taikymo veiksnys. Teisès problemos, 2010; 2(68): 58-91.

\section{APPLICATION OF PSYCHODIAGNOSTIC ASSESS- MENT IN EXPERT PRACTICE \\ G. Butkus}

Key words: psychological research, forensic psychological expertise, normative and interpretive paradigm.

Summary

The aim of this study is to analyse the peculiarities of the work methods of a forensic psychologist as well as to evaluate the practical demand for psychological evaluation in perspective. The problem analysed is the integration of normative (quantitative) and interpretive (qualitative) research strategies in forensic psychologist activity. Having analysed legal expert documentation, scientific psychological evaluation literature and the results of forensic psychologist practice, the following conclusions were drawn: 1 .
The methodical complexity of psychological research of forensic psychologists depends on the type of forensic examination: a single-person forensic psychology examination or a psychological research in the framework of forensic psychiatry. 2 . In the context of forensic psychiatry, psychological tests have the characteristics of interpreting paradigm, case study and quality research, the variety of which depends on the aims of the client. 3. The prospective task of forensic psychologists is to provide special knowledge on the assumptions of the individual psychological peculiarities of a person, including the presumptions for maturity and possible behaviour correction, which may render beneficial to court in deciding the limits of criminal liability and sentence.

Correspondence to: gintaras.but@gmail.com

Gauta 2015-10-01 